Women's Studies

An inter-disciplinary journal

ISSN: 0049-7878 (Print) 1547-7045 (Online) Journal homepage: https://www.tandfonline.com/loi/gwst20

\title{
Reconceiving the Terrible Mother: Female Sexuality and Maternal Archetypes in Kate Chopin's The Awakening
}

\section{Amanda Kane Rooks}

To cite this article: Amanda Kane Rooks (2016) Reconceiving the Terrible Mother: Female Sexuality and Maternal Archetypes in Kate Chopin's The Awakening, Women's Studies, 45:2, 122-141, DOI: 10.1080/00497878.2015.1122505

To link to this article: https://doi.org/10.1080/00497878.2015.1122505

曲 Published online: 03 Mar 2016.

Submit your article to this journal $₫$

III Article views: 1352

Q View related articles ¿

View Crossmark data $₫$

Citing articles: 1 View citing articles ¿ð 


\title{
RECONCEIVING THE TERRIBLE MOTHER: FEMALE SEXUALITY AND MATERNAL ARCHETYPES IN KATE CHOPIN'S THE AWAKENING
}

\author{
AMANDA KANE ROOKS \\ Central Queensland University, Australia
}

Many critics have noted the imitative nature of Kate Chopin's The Awakening when considered in light of its fictional predecessors, including The Scarlet Letter, Madame Bovary, Anna Karenina, and Effie Briest. Chopin's novel clearly participates in a nineteenth-century-narrative concern for the plight of Victorian women as objects in marriage and motherhood. References in critical works to The Awakening as an "American Bovary" in particular certainly seem justified: both Emma Bovary and Edna Pontellier, in their inability or unwillingness to conform to middle-class convention, become bored with their husbands, neglect their offspring, take two lovers (one inexperienced and earnest, the other a philanderer), and ultimately commit suicide. Despite a clear replication of premise and theme, however, Chopin refuses to conform to the conventional standards of style established by the fiction of her predecessors. Her novel constitutes a mingling of naturalism, realism, and symbolism, perhaps more reminiscent of the earlier Romantics than the realists with whom her work has so frequently been compared. Indeed, it is at least in part the novel's deviation in style that assists in constituting it as arguably the first in the nineteenth-century tradition of the fallen woman plot to offer a truly focused and determined engagement with the multifaceted construction of Mother love and its intrinsic relation to female sexuality. While a number of critics have noted Chopin's use of mythological figures from classical antiquity in constructing her heroine's sexual awakening, ${ }^{1}$ what has been largely overlooked is the way in which various specifically maternal archetypes steeped in myth manifest in Edna's subconscious and serve to illuminate and complicate her sexual transformation.

In The Archetypes and the Collective Unconscious Jung attributes both creative and destructive tendencies to the primordial Mother archetype. An examination of various mythological motifs found in artistic creations since Paleolithic times contributes to Jung's argument that within the collective unconscious, the Mother has been divided from herself and split into two separate deities: one that represents "all that is benign, all that cherishes and sustains, furthers growth and fertility"; and

Address correspondence to Amanda Kane Rooks, Office of Research, Central Queensland University Australia, Bldg. 32, Level 2, Bruce Highway, North Rockhampton, Queensland 4701, Australia. E-mail: a.rooks@cqu.edu.au

${ }^{1}$ These criticisms include Wayne Batten's "Illusion and Archetype: the Curious Story of Edna Pontellier" (73-88), Sandra Gilbert's "The Second Coming of Aphrodite: Kate Chopin's Fantasy of Desire” (42-56), Cristina Giorcelli's "Edna's Wisdom: A Transitional and Numinous Merging" (109-48), and, most recently, Angela Hailey-Gregory's “'Into the Realms of the Semi-Celestials': From Mortal to Mythic in The Awakening” (295-312). 
the other that "devours, seduces, and poisons" (82). In his claim that mothers are invested with "authority and numinosity" as a result of being attributed a "mythological background," Jung asserts the significance of our collective relationship with the Mother archetype to our relationship with the personal mother (83). More recently, Anthony Stevens has referred to the nature of this relationship in terms of how it occurs on a "predominantly unconscious level of psychic activity," while John Carroll has suggested the burden of the archetype, how it has long contributed to the constitution of the Mother as both the source of and solution to all manner of personal and societal ills (Stevens 110; Carroll 114). The Awakening appears to offer a comment on the very nature and function of the archetype, and on the mutability of its expression as demonstrated in the variance of its manifestation according to the given cultural and historical moment. More specifically, Chopin connects our collective relationship with the archetypal mother figure (in this case gleaned from engagement with various mother figures from classical myth and tragedy) to a uniquely Victorian construction of the Mother.

Perhaps nowhere was the "split" as exemplified in Jung's Good and Terrible Mother more pronounced than throughout the nineteenth century, when the Mother came to be defined by her purity, superior morality, and selfless devotion to family. At the heart of the insistent veneration of the Virgin Mother at this time was at least in part a deeply embedded fear over the threatening potential of women's sexuality. The assertion of the Mother's heavenly ordained virtue, it seems, would ensure the suppression of her dangerous sexuality in favor of the necessities of reproduction and the nuclear family. By the time Chopin was penning The Awakening, however, the appeal of sanctified motherhood was clearly beginning to wane in some quarters. In the United States, in particular, the expansion of women's opportunities for legal and economic independence and the advent of the New Woman saw many young women reject the self-sacrificial ideal of True Womanhood in favor of the values of personal freedom and fulfillment. At the same time, the celebration of the unimpeachable Angel in the House ${ }^{2}$ found in the midcentury popular women's novel began to give way to a literary skepticism that positioned the Mother as a force to be avoided, escaped, and even repulsed. In the popular works of Mark Twain, for example, she had become an insipid and meddlesome presence, one that must be hoodwinked and deceived by Huck Finn and Tom Sawyer in their quest for freedom and pleasure. Earlier writers had already seen her oppressive potential take on a far darker, more malevolent tone: Dickens' popular works, for example, are rife with callous and deficient mothers. The mother was increasingly relegated to a minor character, or a recollected figure, one consistently

\footnotetext{
2 "The Angel in the House," a narrative poem by Coventry Patmore (1864), enjoyed significant popularity throughout the mid- to late-nineteenth century. The poem takes as its subject Patmore's self-effacing wife, whom he venerates as the ideal woman. The term "angel in the house" came to be synonymous with the Victorian feminine ideal: the wife and mother singularly devoted to the needs of her husband and children. The ubiquity of the Angel in the House in representation and debate attested to the new and unprecedented distinction given maternity and domesticity at this time (for more on The Angel in the House, see Shari Thurer's The Myths of Motherhood: How Culture Reinvents the Good Mother, 182-210).
} 
representative of the force against which the individual must assert and define their autonomy.

While Chopin appears to share the cynical vision of the Angel in the House emerging in the fiction of many of her contemporaries, her novel brings the mother figure back to the narrative center and attempts to revive her via a focus on her sexuality. Despite women's increasing freedoms at the fin de siècle, widespread public debates around sexual morality clearly suggested that women's sexual autonomy was far from being realized. Congruently, the Victorians' fetish for the Madonna went largely unabated and sanctified motherhood persisted as the only acceptable expression of maternity, albeit one increasingly undermined by a declining faith in mothers' role. This article examines how The Awakening confronts readers with the primordial archetype in simultaneously associating maternality with all that is nurturing, solicitous, and benign, as well as all that is devouring, seductive, and castrating. More specifically, I argue that the provocative nature of The Awakening, in terms of persistent Victorian discourses of motherhood and women's sexuality, lies in its acknowledgment that the figure of the Madonna is merely an extension of the Great Mother archetype, that this paragon of virtue cannot exist in such flawless illumination except in relation to her dual aspect, the Terrible Mother.

One of the persistent defining characteristics of the Terrible Mother in myth is her alleged prioritizing of her sexual desires over her maternal responsibilities. The Greek mythological imagination was certainly notable for its omission of nurturing mothers: Medea, Phaedra, Agave, Jocasta, Hera, and Clytemnestra all attest to the sexually infused, destructive power of the Mother. Mothers were frequently demonized as perverse, malevolent, or debased and often projected into vitiating and devouring monsters (think Echidna, Charybdis and Scylla, Lamia, and the Gorgons). Chopin's resurrection of various mother figures from classical myth and tragedy serves to de-sublimate the Terrible Mother and in so doing, it offers an antidote to the sentimental visions of ideal motherhood deeply entrenched throughout much of the nineteenth century. The novel's simultaneous juxtaposing and fusing of the Terrible Mother from classical antiquity with the Madonna-inspired True Woman of the Victorian era ultimately serves to illuminate the ways in which the Mother's sexuality consistently bears on her standing as a figure simultaneously loathed and revered, feared and desired.

Chopin's concern for the Victorian cult of the Madonna and its implications for women's sexual and maternal performances is perhaps most evident in her construction of the narrative's "mother-women" (9). The novel's representation of the self-abnegation demanded by the Victorian social and religious institution of motherhood is communicated via a thinly veiled tone of derision: "they were women who idolized their children, worshipped their husbands, and esteemed it a holy privilege to efface themselves as individuals and grow wings as ministering angels" (9). In the opening chapter, Chopin blatantly sets her heroine apart from the other mother-women of Grand Isle: "In short, Edna Pontellier was not a mother-woman" (9); however, the novel's pre-eminent mother-woman, Adèle Ratignolle, serves as an 
undeniable source of enchantment where Edna is concerned. Adèle is "the embodiment of every womanly grace and charm" (9). Her construction in the narrative explicitly harks back to earlier visions of sanctified womanhood: "there are no words to describe her save the old ones that have served so often to picture the bygone heroine of romance and the fair lady of our dreams" (9). Chopin's dissection of Adèle's appearance reinforces this character's mythical status: "the spun-gold hair that comb nor confining pin could restrain; the blue eyes that were like nothing but sapphires; two lips that pouted, that were so red one could only think of cherries or some other delicious crimson fruit in looking at them" (9). Edna likes to "sit and gaze at her fair companion" (12) and further morselizes Adèle in her frequent noting of her friend's "perfect" and "exquisite" hands $(10,12)$. In her hyperbolic state of adoration, Edna even imagines Adèle as some kind of "faultless Madonna" (12).

Despite Edna's repeated praises, the tone of Chopin's representation of Adèle in the opening chapters certainly seems to undermine any serious reverence for this character. Ivy Schweitzer has noted the ways in which Chopin recalls a distinctly Victorian "popularized erotics of maternal sacrifice and a spiritualization of feminine beauty" in her portrayal of Adèle (173). According to Schweitzer, in constructing Adèle as a "sensuous Madonna," Chopin demonstrates the ways in which power is denied women in a patriarchal world, how in embodying all that is both sensuous and saintly, women are effectively objectified, fetishized, and silenced (13, 173). Katherine Kearns likewise attributes Adèle's appeal to this character's acceptance of "a masculinist definition of self-hood" (73). Certainly, Chopin hints at the thin veneer of the Victorian glorification of Mother by initially positioning Adèle's allure as essentially hollow and contrived; the novel suggests that "there was nothing subtle or hidden about her charms" (9), that she possessed a "candor . . [about her] ... whole existence, which every one might read" (17). Kathleen Lant has similarly noted how Adèle's initial introduction to the narrative leaves the reader "skeptical of her mythical status" (9) and notes that Chopin's construction of this character as a "bygone heroine" connects her with a passing world order (171). In her more recent contention that the novel's description of Adèle contains "the implication that she, and all such mother-women, will soon be rendered extinct" (46), Katie Berry Frye similarly asserts the obsolete standing of the quintessential mother-woman's charms.

Yet while Edna's reverential regard for Adèle might typify the patriarchal order's mode of denying power through the fetishizing of the mother figure as Madonna, Chopin's construction of Adèle ultimately to attributes this character a potency that does not appear to be entirely accounted for in such readings. Adèle not only strikes a pronounced contrast to the increasingly officious and unappealing literary mother figure emerging in the late-nineteenth century, she ultimately proves to be a pivotal force in the narrative. It is arguably Adèle who provides the motivation for Edna's sexual awakening and who propels Edna towards her final, tragic demise. Adèle's grip on the novel's heroine is unrivaled by any other character in the narrative and, despite Schweitzer's claim that she is silenced as a result of her objectification, Adèle literally has the final word via her entreaty to Edna to "think of the children" (143). Such particulars compel the reader to consider 
Adèle's construction as offering far more than a mere foil to Edna's feminist sympathies. They also inspire a reading of the text that runs counter to much of the novel's scholarship, which tends to position Adèle as antithetical to Edna due to this character's alignment with ideal Victorian womanhood. ${ }^{3}$

Adèle's potency is attributable to the fusing of the maternal and sexual elements of her nature. ${ }^{4}$ While the popular manifestation of mothering exemplified by the women at Grand Isle might seem at odds with Edna's sexual desires, Adèle's ostensibly orthodox maternal and domestic performances hold an undeniable sexual appeal. Adèle's presence in her own home is suggestive of some kind of divine, sexualized domesticity: "she looked more beautiful than ever . . . in a negligee which left her arms almost wholly bare and exposed the rich, melting curves of her white throat" (69). Adèle's comforting of Edna takes on a maternal character and is infused with sexual overtones: her "caresses" and "strokes" and her consolatory comment, "poor dear," leave Edna "flushed and . . . intoxicated" (22). Edna's would-be lover Robert reveals that his past worship of Adèle also involved a mingling of her maternal and erotic aspects, as he flippantly complains of Adèle's excessive requests, of his blind adoration toward her, of his seeking of "whatever crumbs of sympathy and comfort she might be pleased to vouchsafe" (12). Despite the strict candor with which Adèle attempts to dismiss Robert's fawning grievances regarding her sexual denial of him, her disconcertion and concomitant reciprocation of sexual desire is inferred in Edna's noting of the fact that "the rose tint had never faded from her friend's face" (14). Adèle's later admonishment of Robert due to his flirtations with Edna also takes on a tone of maternal authority, yet the parallel presence of the "intruding lovers ... exchanging their vows and sighs" (23) implicates the thinly veiled sexual possessiveness behind her reproach. ${ }^{5}$

Evidently, Chopin's alignment of Adèle with the high Victorian maternal icon of redemption refuses to sublimate this character's sexuality in favor of her maternity. While other critics have also noted this (Carolyn Matthews, for example, even contends that Adèle's "maternal qualities are often overshadowed by an erotic appeal" (12)), such observations are frequently countered with the suggestion that Adèle's sexuality is only enacted within the accepted bounds of patriarchal marriage

\footnotetext{
${ }^{3}$ Frye, for example, constructs Adèle as "the litmus test against which Edna is evaluated and revealed as not a mother-woman, [but] as a grotesque” (45). Kathleen M. Streater's more recent article, however, revives Adèle in challenging many of the criticisms that have erroneously assumed this character's passivity and lack of carnal desire due to her classification as mother-woman (406-15). Streater's contribution is striking in terms of its positioning of Adèle's sexual performances as even more noteworthy than those of the novel's heroine, thereby offering a challenge to criticism's frequent overshadowing of Adèle's sexuality in favor of Edna's.

${ }^{4}$ As the examples offered in this paragraph attest, Adèle's fusing of the maternal and sexual is almost entirely disconnected from her children. It would appear that, while a merging of maternal and sexual expressions is acceptable (perhaps even expected) in what might be considered a peculiarly womanly form of relating, paradoxically, applying such a model to actual mothering practices would be held under deep suspicion.

${ }^{5}$ Adèle's sexually derived consternation is further insinuated in her reception of Robert's conciliatory cup of bouillon, another episode focusing on her inaccessible fleshly allure: "she thrust a bare, white arm from the curtain which shielded her open door, and received the cup from his hands” (25).
} 
and motherhood, that it is a manifestation of the workings of this character's concession to be objectified via what Matilde Marin Gonzalez refers to as the "hysterization of her body" (375). Margaret Brown argues that Adèle's sexuality is "defused and made 'safe' because it is channeled into the very visible production of children" (46); Brown attributes Adèle's appeal to her fecundity rather than her sexuality, a reading that positions this character as strictly embodying the Virgin's "combination of passionless sexuality and maternal feeling" (45). Likewise, Schweitzer refers to Adèle as "a surface of clichés" that equate femininity with maternity and concomitantly position womanhood as "incompatible with female desire, autonomy, or independent subjectivity" (169). Yet, arguably, there is something far more seditious and threatening about the construction of Adèle's sexuality, particularly as it relates to her performance of maternality. Indeed, there are hints of chaotic forces at play in Adèle's otherwise sentimental representation that clearly align her with Jung's Terrible Mother, and position her as much the Medusa as the Madonna.

The inference of Adèle's potentially devouring nature is perhaps most readily perceived in the narrative through her connection with the sea. Just as Adèle spurs Edna's sexual awakening via her physical caresses and tender verbal sympathies, "The voice of the sea speaks to the soul. The touch of the sea is sensuous, enfolding the body in its soft, close embrace. The voice of the sea is seductive; never ceasing, whispering, clamoring, murmuring, inviting . . ." (16). Like Adèle, the sea provides both maternal comfort and erotic appeal. Yet the "sonorous murmur" of the Gulf also represents an influence that is "necessarily vague, tangled, chaotic, and exceedingly disturbing," inspiring Edna's disquieting and prophetic contemplation regarding "how many souls perish in its tumult" (16). While Robert earlier hints at Adèle's destructive propensities in referring to "the cruelty beneath that fair exterior" (12), it is during her accouchement (the definitive by-product of mothers' sexuality) that Adèle's link to the shadowy, chaotic face of the sea is most evident. Here, Adèle strikes a stark contrast to her previous positioning as a "ministering angel." Now, "nervous," "drawn and pinched," she is filled with "suffering impatience" (140) and cruel intention, wishing the doctor dead and rebuking everybody for their inattention to her condition. Adèle's state of maternal ferocity clearly demonstrates how mothering requires far more than the docility expressed in the Victorian vision of the Madonna.

Chopin's alignment of Adèle with the seductive, tumultuous sea is offered further significance via its engagement of the serpent motif. The state of Adèle's hair during her accouchement, "coiled like a golden serpent," provides a sinister connection to the "foamy wavelets coiled like serpents" around Edna's ankles as she enters the sea, seeking her death $(140,148)$. Adèle's "pure white" apparel, which includes billowing "white skirts," "draperies and fluttering things" (18), resembles the sea to which Chopin ascribes a palpable sense of the erotic, again, via reference to the serpent: it "swelled . . . in broad billows that melted into one another . . . in little foamy crests that coiled back like slow, white serpents" (18, 14, 18, 33). Jung links the image of the serpent to the mater saeva cupidinum, the "savage mother of desire" who is given to "orgiastic frenzies and barbaric extremes," which threaten the 
fate of the hero of classical antiquity (Symbols of Transformation 312, 389). The snake motif in the novel certainly conjures various monstrous projections of the mother, linking Adèle perhaps most readily to the Medusa, to whom Freud, in Sexuality and the Psychology of Love, would later attribute the symbolism of castration anxiety associated with maternal sexuality (212-13). In her association with the serpent, Adèle also evokes Echidna-half snake, half seductive nymph-the mother of numerous Greek monsters, as well as Lamia, the beautiful queen of Libya who is transformed into a child-eating daemon with a serpent's tail. In her construction of this character as the "siren of Grand Isle" (167) Lant sees Adèle morphing into another threatening form. As muse or siren, Adèle's association with elemental forces is suggested via the "stiff wind that whipped the water into froth" (19) as she inspires Edna's initial stirrings of sexual desire upon the ocean shore. The effect of Adèle's bestowing of affection upon Edna, which leaves her friend "muddled . . . like wine," mirrors the influence of the siren's song, which, according to Walter Caplan Perry at the turn of the century, "lapped both body and soul in a fatal lethargy, the forerunner of death and corruption" (Chopin 22; Perry 163). Indeed, Edna's Adèle-inspired sensual arousal appears to prove both undeniable and ill-fated.

Such monstrous projections are manifestations of what Jung referred to in Symbols of Transformation as the mother "who might not be touched" (370). Yet the destructive Mother's allegedly antithetical aspect, the gentle Virgin, can surely also be included in this untouchable category, given her heavenly ordained virtues. In their work on the transformation of goddess imagery through history, Marion Woodman and Elinor Dickson contend that "what is repressed out of fear reemerges in the form of its repression” (22). Accordingly, Chopin's construction of Adèle exposes how the very act of denial inevitably brings that which has been denied to light. The novel reveals the way in which the image of the chaste Madonna necessarily calls on its dualistic aspect, the salacious devourer, how in Adèle's attempts to embody the Good Mother, she inadvertently resurrects the Terrible Mother who must at the very least be exploited as a point of orientation. In this sense, Adèle's construction challenges her society's denial of mothers' sexuality as well as its insistence on mothers' unwavering benevolence, thereby undermining the disembodied forms upon which mothers were expected to model themselves. Indeed, it is in alternately associating Adèle with both the nurturing and devouring aspects of the archetype that the novel exposes the ways in which various human characteristics and desires are denied women as a result of the "distorted forms," or "neurotic fantasies," as Woodman and Dickson might have it, that inform the expectations and performance of motherhood (22-23).

Where Adèle both embodies and distorts such fantasies, Edna's construction represents perhaps a more discernible, resolute rejection of them. Edna perceives motherhood as a "responsibility ... for which Fate had not fitted her," and considers her children "antagonists" who "sought to drag her into their soul's slavery" $(22,147)$. It would seem that the more Edna entertains her erotic impulses, the more she is given to taking on mythical forms that appear to preclude her maternity. In her essay "The Second Coming of Aphrodite," Gilbert connects Edna to the 
goddess Aphrodite, both of whom are (re)born of the sea and whose definitive character can be found in their association with love, beauty, and sexual rapture (42-66). Edna is clearly constructed in visual association with the goddess upon her literal awakening to Robert after her long, swim-induced sleep, which finds her face glowing and her clothes and hair both loosened. Indeed, the novel explicitly connects these two figures at the climax of the feast: "Venus rising from the foam could have presented no more entrancing a spectacle than Mrs. Pontellier, blazing with beauty and diamonds" (145). Yet, in relation to maternality, Aphrodite may not entirely embody the redemptive figure outlined in Gilbert's work. After all, Aphrodite arguably prioritizes sexual passion alone, not its potential result (a state of maternity). Further, both figures are born of the father (Aphrodite was born of Uranus' genitals, while Edna was raised by her father with no mother she can recall), so maternality is once again seemingly consigned to absence and split off from the pursuit of the sensually erotic.

Edna's growing awareness of her sexuality also sees her increasingly associated with far more strange and terrifying mystical forces. In response to her rising sexual impetuosity, "the shadows lengthened and crept out like stealthy, grotesque monsters across the grass" (47). The images of "misty spirit forms . . prowling in the shadows among the reeds" and "the phantom ships, speeding to cover" (48) link her with the likes of the sea nymph Scylla, whose monstrous form was conferred upon her by the sorceress, Circe, as a result of sexual jealousy. Scylla's fury and loathing over her transformation were understood to have prompted her penchant for feasting on the bodies of sailors passing through the Strait of Messina, thereby connecting her devouring potential to her sexual allure. The destructive potential of Edna's sexuality, its association with death, is again foregrounded via an eerie allusion to the toll required for the ferry to cross the river Styx to the underworld: "Edna could hear the whispering voices of dead men and the click of muffled gold" (48). In reflecting on her increasingly reckless flirtations with the notorious cad Alcee Arobin, Edna herself seems conscious of her association with the devouring, monstrous feminine: "in all the codes which I am acquainted with, I am a devilishly wicked specimen of the sex" (105).

Yet Edna's construction ultimately challenges the positioning of maternity and sexuality as antithetical, as her sensual awakening induces her not only to hyperbolic expressions of the threatening aspect of the archetype as we have seen, but also to the maternally nurturant aspect. Edna's sexual interludes with Alcee prompt her to spend a week with her children who are away in Iberville. Here, the temporary satiation of Edna's sexual yearnings prove to have a discernible impact on her maternal performance: "She wept for very pleasure when she felt their little arms clasping her; their hard, ruddy cheeks pressed against her own glowing cheeks. She looked into their faces with hungry eyes that could not be satisfied with looking. . . She lived with them a whole week long, giving them all of herself, and gathering and filling herself with their young existence" (121). Such descriptions certainly belie Edna's earlier perception of her children as hostile impediments to her sense of autonomy. Indeed, Edna's maternal performances are variously punctuated with episodes of 
warmth and affection throughout the novel, a tendency that sees her embody the ambivalence of the unified Mother archetype: "she was fond of her children in an uneven, impulsive way. She would sometimes gather them passionately to her heart; she would sometimes forget them ... when they were away she did not miss them except with an occasional intense longing" (22). The ambivalence that defines Edna more generally is expressed in Chopin's description of her appearance as being "captivating by reason of a . . contradictory subtle play of features" as well as by the "conflicting sensations" $(4,107)$ that frequently assail this character. Interestingly, despite Edna's clear deviation from the maternal ideal, Chopin hints that her children are perhaps better adjusted than those of Grand Isle's other mother-women. In contrast to the novel's "other mother-tots," Edna's boys are described as "sturdy little fellows" $(11,2)$ : "If one of the . . boys took a tumble whilst at play, he was not apt to rush crying to his mother's arms for comfort; he would more likely pick himself up, wipe the water out of his eyes and the sand out of his mouth, and go on playing" (9).

Regardless of the potential benefits presented by Edna's mothering style, the ambivalence she embodies is obviously a force that must be repressed for the sake of social propriety. Indeed, Edna's disclosure to Adèle in which she refuses to conform to the Victorian sacrificial model of mothering ("she would never sacrifice herself for her children, or for any one") leads to a "heated argument" in which "the two women did not appear to understand each other or to be talking the same language" (59). It would appear that in a world governed by the principles of dissociation, where human behaviors and expressions are separated into either "good" or "bad" dichotomous arrangements, the disorder that the Great Mother archetype embodies represents what Woodman and Dickson posit as the "shattering of rigid categories" (45), including the maternal/sexual divide. Although the reader is made privy to the Terrible side of Adèle's nature, for Adèle herself, this aspect of her identity is largely exiled to the unconscious. It is inarguably Edna who most willfully acknowledges and exercises the subversive disorder represented by her maternal ambivalence as, in her pursuit of sexual fulfillment, she consciously aligns herself with "life . . . that monster made up of beauty and brutality," and, as a result, feels "neither shame nor remorse" (107). Woodman and Dickson's claim that embracing the "chaos" of the archetype "can resurrect us into a higher wisdom" (45) is ultimately reflected in Edna's position as "having descended in the social scale, with a corresponding sense of having risen in the spiritual" (121).

In her seeking of a "higher wisdom" Edna appears to be explicitly aligned with the Hero archetype of classical antiquity. Indeed, Edna's journey mirrors many of the fundamental structures and stages of the classical hero's journey as outlined by Joseph Campbell in The Hero with a Thousand Faces. Just as the hero's "call to adventure" involves the transferal of "his spiritual center of gravity from within the pale of his society to a zone unknown" (58), so too does Edna experience the feeling that she is "being borne away from some anchorage which had held her fast, whose chains had been loosening" (42). The hero's passage into "a region of 
supernatural wonder" where "fabulous forces are there encountered" (Campbell 30 ) is initially signaled in the novel by the "mystic spirit" who, in seeking one who is "worthy of being exalted ... into the realms of the semi-celestials" $(42,35)$, inspires Edna's first bold swim far out into the ocean. It is the ocean, which leaves Edna both "intoxicated" and filled with "a certain ungovernable dread" (34), that represents what Campbell refers to as the "fateful region of both treasure and danger" (58) into which the hero must journey. Yet, ultimately, it is Edna's striking deviation from the hero monomyth that enables this "new" heroine to embody the chaos necessary for the attainment of the higher wisdom to which Woodman and Dickson refer. Where the hero myth involves a necessary triumph over a frequently feminized monstrous force (e.g., Perseus and the Medusa, Heracles and the Hydra, Jason and the Harpies), Chopin's heroine instead assimilates the threatening feminine forces she encounters into her own identity.

This assimilation is perhaps most readily suggested via what appears to be Edna's gradual metamorphosis into Adèle, as the Madonna/Medusa. In the early phase of the narrative, Edna is constructed as Adèle's antithesis as Chopin attributes a particular hardness and pragmatism to her character. She has a "severity of poise and movement" that renders her "statuesque" $(18,19)$, and in her "habitual reserve" there is no sign of the "supercilious or over-dainty . . no cat-like suggestion of voluptuous ease" $(17,36)$. Yet after the "first-felt throbbings of desire" (37) inspired by her daring swim, descriptions of Edna now suggest she is far more animated, infused with warmth, and linked to the natural world around her. Her resemblance to Adèle, the angel in white with the "rose tint" and "splendid color," is unmistakable as her "face was flushed," "her eyes flamed with some inward fire that lighted them," and "her head, set off by her dainty white gown, suggested a rich, rare blossom" (14, $13,51,65,51)$. Edna is influenced by the animal suggestiveness of Adèle's coquettish attentions toward her father, referred to in the novel as "a kittenish display" of "feline or feminine wiles" (86). This episode appeals to "the animalism that stirred impatiently within [Edna]" (99), and soon after the doctor notes her newfound radiance: "a subtle change . . . had transformed her from the listless woman he had known into a being who, for the moment, seemed palpitant with the forces of life. Her speech was warm and energetic. There was no repression in her glance or gesture. She reminded him of some beautiful, sleek animal waking up in the sun" (88). The environment surrounding Edna also transforms. In her garden, "all the mystery and witchery of the night seemed to have gathered . . . amid the perfumes and the dusky and tortuous outlines of flowers and foliage," again linking Edna to Adèle whose room is "cool and sweet with the odor of great roses" (65).

The erotic symbolism of the flower in the novel is made plain in the description of Arobin's attraction toward Edna: "He had detected the latent sensuality, which unfolded under his delicate sense of her nature's requirements like a torpid, torrid, sensitive blossom" (134). The novel's flower motif again recalls Aphrodite/Venus, whose representation in Botticelli's Birth of Venus finds the passionate Zephyros breathing roses upon the goddess. The passion, bliss, and beauty of human sexuality are suggested by such an allusion, yet the eroticism implied in the narrative's 
floral imagery is also tainted with a sense of foreboding: the "voices" working to seduce Edna in her garden "came from the darkness" and "were not soothing" but "mournful" and jeering, "without promise, devoid even of hope" (65). In this way, the novel's flower motif serves to combine the life-affirming quality of sexual passion implied in the image of the Venus with the paradoxical suggestion of the destructive nature of carnal lust found in Old Testament mythology. Indeed, such imagery is evocative of the linking of women and carnal sin found in biblical discourse as part of an excessive concern for establishing the boundaries between good and evil. Edna's mirroring of the Fall of Eve has already been implied in the establishment of her link to the phallic image of the snake. The allusion to Edna's tasting of the forbidden fruit (the ultimate symbol of carnal desire) is further reinforced via the image of her enthusiastic devouring of the nourishment her anticipated lover, Robert, procures for her: "she bit a piece from the brown loaf, tearing it with her strong white teeth. She poured some wine into a glass and drank it down" (46). In bold mockery of its biblical derivation, Chopin even goes so far as to have Edna pluck an orange from a tree to throw at the object of her desire. The eroticism permeating this episode is further evinced by Robert's keen response to Edna's transformation, as he looks on with pleasure, "gratified to discover her appetite" (47).

The sensuous appeal of the blossoms, the foliage, the perfumes and the physical beauty, all associated with the novel's foremost mother-woman, Adèle, are linked to the dark energies- those "vague, tangled, chaotic, and exceedingly disturbing" (16) forces working on Edna, intoxicating and mystifying her, provoking her to act upon her sexual desires. In this way, the novel's use of biblical symbolism in its construction of Adèle clearly reaches beyond the exploitation of the Virgin, as previously outlined, to the allegorical figure of evil, the Whore of Babylon, from Revelation. The Whore, an allegory for an evil pagan Roman Empire, tellingly takes the form of the Terrible Mother, a tempting menace who feeds on the "blood of the saints" and who will make the weak "drunk with the wine of her fornication" (Holy Bible, Rev. 17:6, 17:2). The vivid colors associated with Adèle and Edna's sensuality (the blossoms, the rosy complexions) mirror the dazzling splendor of the Whore "arrayed in purple and scarlet color" (17:24). The wine motif in the novel is attributed the libidinal significance of the Whore metaphor. Indeed, Edna's unraveling sexuality is connoted by her increasing consumption of wine. Others are also held under the spell of the Whore: the fawning Victor is compelled to serenade Edna with the suggestive "ah si tu savais" (115) after having drained his glass of wine at the novel's climactic scene of the feast. The sexual overtones of Edna's impetuous response to Victor's attentions are unmistakable as she shatters her own glass of wine, which "spilled over Arobin's legs and . . . trickled down upon Mrs. Highcamp's black gauze gown" (115). Even the novel's hardened, cynical Mademoiselle Reisz is "bewildered" by Edna's charms at her host's celebratory dinner after having "tasted the good, rich wine" (114). Mademoiselle Reisz's erotically infused deference toward Edna upon her departure, which sees her bestow her friend with a "kiss ... upon the shoulder" as she whispers, "Bonne nuit, ma reine" (114), recalls the 
enticing yet aberrant power of the Whore who "saith in her heart, I sit a queen, [yet] I am no widow" (Rev. 18:7).

The novel's use of the Whore of Babylon allegory serves to challenge oppressive Christian strictures on the feminine and on sexual love, which are both frequently exploited in biblical symbolism as expressions of evil. Chopin's concern for the biblical tendency to equate female sexuality with sin is further evidenced in the Whore's ominous parallel motif in the novel: the "creeping" $(26,41)$ lady in black with her Sunday prayer book and beads, unceasingly pursuing the infatuated lovers. Edna's deliberate alignment with the Whore denies the hero's conventional path as she refuses to partake in what Jung refers to as "the battle for deliverance from the Mother" (Symbols of Transformation 274). Where the hero of antiquity's triumph over various malevolent Great Mother derivatives arguably constitutes an obsessive dissociation of the maternal/feminine from its threatening forms, Edna's construction calls for a new kind of conquest whereby the hero embraces the ambivalence of human nature. After all, as Jung notes, "the power of the Terrible Mother is irresistible, coming as it does from the unconscious" (Symbols of Transformation 370). Chopin would see her heroine salvage what lies dormant within and rise to the related challenge implicit in Woodman and Dickson's claim that "the chaos ... we fear is the very thing that can free us" (45). In this way, Chopin reclaims the quintessential biblical image of sin, transforming the Whore from presentiment of end times to harbinger of a new and necessary consciousness.

In the novel, the quest for this new consciousness is initiated through Edna's heeding of the maternal voice of the sea, the novel's ultimate symbol of the unified Mother. The sea's ambivalence, its simultaneously nurturing and destructive nature, is revealed in its "sonorous murmur," which is "a loving but imperative entreaty" that leaves Edna feeling "strange and awful" yet also "delicious" $(19,148)$. The ominous allure of the sea is captured in the novel's refrain: "The voice of the sea is seductive, never ceasing, whispering, clamoring, murmuring, inviting the soul to wander in abysses of solitude" (88). Moreover, Chopin's construction of the maternal sea aligns with the symbolism of water in the hero's journey according to Jung: "water represents the maternal depths and the place of rebirth; in short, the unconscious in its positive and negative aspects. But the mystery of regeneration is of an awe-inspiring nature: it is a deadly embrace" (Symbols of Transformation 389).

Edna's salvation lies in her embracement of the threatening, eroticized maternal sea, the incarnation of her own ambivalent, unconscious energies. In this sense, it is possible to read Edna's final act not as a literal suicide, but as a metaphorical rebirth. Edna's swim into the ocean has the quality of a baptism; it symbolizes her transition from ignorance to knowledge, from bondage to freedom, as it bestows a biblical sense of "newness of life" (Rom. 6:4). Edna experiences a "newly conquered power" after her first swim, described further on as a new "understanding" as if "a mist had been lifted from her eyes, enabling her to look upon and comprehend the significance of life" $(34,107)$. Indeed, the imagery of the novel's final scene is replete with suggestions of new life, including Edna's feeling of being "like some new-born creature, opening its eyes in a familiar world that it had never 
known" (148). The novel's closing symbols of the oppressive nature of nineteenthcentury cultural scripts for feminine performance, including the "dog chained to the sycamore tree," the "voice" of Edna's dominating father and her matronly sister, and the sexually menacing "spurs of the cavalry officer" (148), are ultimately superseded by the novel's final, hopeful image, which is suffused with a sense of fecundity and eroticism, a sense not of an ending, but of a new beginning, where "the hum of bees, and the musky odor of pinks filled the air" (148).

In her exploration of the psychological and feminist significance of fictional water-deaths, Mary Jane Lupton has noted how drowning or "immersion in water" can be read "metaphorically as 'going below the surface,", as a form of "rebirth, a return to air, a baptism" (95). Gilbert also suggests the possibility of reading Edna's final act as one of regeneration rather than annihilation: "Edna's last swim is not a suicide ... [but] a death associated with a resurrection, a pagan, female Good Friday that promises a Venusian Easter" (57). According to Gilbert, Edna's final act can be interpreted as a swim "not into death but back into her own life, back into her own vision, back into the imaginative openness of her childhood" (57). In this sense, Edna's drowning can be situated within the belly of the whale, that part of the hero's journey that demonstrates a willingness to metamorphose: "The hero . . . is swallowed into the unknown and would appear to have died. . . This popular motif gives emphasis to the lesson that the passage of the threshold is a form of self-annihilation .... But here, instead of passing outward, beyond the confines of the visible world, the hero goes inward, to be born again" (Campbell 90-91). Yet in the conventional hero's journey such a rebirth necessarily encompasses a victory over the woman as temptress. According to Campbell, "the seeker of life beyond life must press beyond (the woman), surpass the temptations of her call" in order to "soar to the immaculate ether beyond" (122). Conversely, Edna's rebirth comes only via an eroticized engagement with the maternal sea which represents that which is generally positioned as intolerable to the hero: "life, the acts of life, the organs of life, woman in particular as the great symbol of life" (Campbell 122). Here, again, Chopin engages in a deliberate transfiguration of conventional imagery from mythology and theology so that the threatening eroticized maternal converts from a symbol of wanton sinfulness and death to one of deliverance and regeneration.

Whether actual or metaphorical, the suicide at the novel's denouement provides for one of the most crucial associations between Chopin's work and that of her fictional precursors. Chopin's imitation of Flaubert and Tolstoy in particular seems obvious; yet, Edna's death at the hands of the embracing sea is arguably far less distressing and brutal than Flaubert's vision of Emma Bovary's protracted, agonized suicide by poisoning, or Tolstoy's suggestion of Anna Karenina's bloodied and disfigured remains after her violent leap under the carriage of a train. Moreover, where Edna's suicide is read not as a literal death, but as a rebirth of consciousness, Chopin offers a far more affirming resolution for her heroine (and for her reader) than many of her literary predecessors addressing the same thematic triad of marriage, maternity, and sexuality. Gilbert accounts for the workings of Chopin's dialogue with the likes of Flaubert and Tolstoy where Edna's suicide and the mythopoetic 
structure of the novel more generally are both concerned: "As she swims . . she swims not only toward a female paradise but out of one kind of novel-the work of Eliotian or Flaubertian 'realism' she had previously inhabited-and into a new kind of work, a mythic/metaphysical romance" (52). In her construction of Edna as "a quasilegendary character in search of a story that can contain her and her power" (55), Gilbert alludes to Chopin's fictionally rendered contention that the parallel plights of Edna Pontellier, Emma Bovary, and Anna Karenina-the story of the woman/mother who desires - cannot be adequately addressed nor indeed contained within conventional fictional modes. Indeed, this contention is explicitly addressed in the novel via Edna's response to the doctor's telling of "the old, ever new and curious story of the waning of a woman's love, seeking strange, new channels, only to return to its legitimate source after days of fierce unrest" (88). For Edna, "the story did not seem especially to impress" for "she had one of her own to tell, of a woman who paddled away with her lover one night in a pirogue and never came back" (88). Again, Chopin implies the need for a leap into the nameless abyss, a shift in consciousness, a new kind of story, as the tale Edna prefers to tell echoes in the pale-faced lovers, "rapt in oblivious forgetfulness, drifting into the unknown" (88).

A distinctly Dionysian flavor permeates Edna's mode of seeking a higher wisdom (or indeed narrative) able to assimilate and reconcile women's sexual and maternal energies. Euripides' fifth-century BCE account of Dionysus' attempts to deify women as part of the demi-god's pursuit of immortality arguably bears semblance to Chopin's fictional call for the established patriarchal order to be overthrown and reconstituted. Many of the novel's aforementioned motifs associated with the Mother goddess (the snake, the wine, the music) also share a close alignment with Dionysus, the Liberator who goads his followers into ecstatic, orgiastic revelry. In the novel, Edna's would-be lover Robert initially provides the most vivid evocation of the figure of Dionysus. After the Pontelliers' evening gathering, it is Robert who "thought of a bath at that mystic hour and under that mystic moon"; he leads the revelers to the symbolic ocean, an act whose motivation is suggested as somehow rooted in a morally ambiguous divine inspiration: "He walked between them, whether with malicious or mischievous intent was not wholly clear, even to himself" $(32,33)$. Edna's response to her previous vision of Robert as emissary of Dionysus (the naked man alone on the seashore, who is also later invoked via the suggestion of Robert's lone walk towards the Gulf [31, 50]) foreshadows her Dionysian transformation: "the very passions themselves . . . aroused within her soul, swaying it, lashing it, as the waves daily beat upon her splendid body" (31). The revelers' journey to the water is redolent of a Dionysian-induced ecstatic frenzy, replete with sexual allusions. The group is buoyed by wine and accompanied by laughter, the strains of distant music, and the musky odors of "damp, new-plowed earth" and "white blossoms" (33). They enter the water, which swelled in "foamy crests [that] . . coiled back like slow, white serpents," "as though into a native element" (33). For Edna, this suggestion of a Dionysian state of possession is ultimately accompanied 
by the seemingly paradoxical yet related Dionysian state of awareness, achieved via a sense of self-overcoming, of standing outside of herself:

She could only realize that she herself - her present self - was in some way different from the other self. That she was seeing with different eyes and making the acquaintance of new conditions in herself that colored and changed her environment. (50)

... she was becoming herself and daily casting aside that fictitious self which we assume like a garment with which to appear before the world. (71)

Although Edna's experience of the ecstatic arguably paves the way for a heightened consciousness in relation to her sexuality, its implications (as rooted in mythology) in relation to maternality, by contrast, would seem rather dire. As female worshipper of Dionysus, Edna is associated with the Maenads, whose rejection of the established order is expressed not only via their unrestrained sexual behavior, but also through their violent murder and cannibalization of children (sometimes their own). This image of the devouring Mother renders the Dionysian dream a nightmare. In the novel it is the anti-mother figure Mademoiselle Reisz who represents the dead to whom the Maenads feed their blood offerings. Mademoiselle Reisz's connection with the Dionysian ideal is hinted in the episode where her touch upon Edna's shoulder "seemed to echo the thought which was ever in Edna's mind ... that she had been denied that which her impassioned, newly awakened being demanded" (57). Indeed, it is the spinster's music that inspires Edna's aforementioned Dionysian vision upon the shoreline; it renders the night "a dream" and transforms the revelers into "uncanny, half-human beings" (35). Mademoiselle Reisz's characterization represents a negation of life and maternality. Her hands are "without warmth," her face is "weazened," her hair is "false" and supports a "batch of rusty black lace with a bunch of artificial violets" plainly evocative of funeral apparel $(73,30,59,30)$. Her aversion to swimming in the (maternal) sea is clearly symbolic, as is her "objecting to the crying of a baby" (30) and her clear loathing of the young Farival twins. Indeed, it is Mademoiselle Reisz, not Edna, who is positioned in the narrative as oppositional counterpart to the hyperbolically maternal Adèle.

Mademoiselle Reisz appears to derive a particular power, and most certainly vicarious pleasure, from the prospect of Edna's sexual transgression (a deviation that would presumably distract Edna from her maternal responsibilities). The novel carries the suggestion of a sexually possessive component to Mademoiselle Reisz's feelings toward Edna, one that inspires her to play for her friend "the quivering love notes of Isolde's song," music with "soulful and poignant longing," and to confess that she is "a foolish old woman ... captivated" (79). Her affection seems to exclude all but Edna, and she expresses antagonism toward all those to whom Edna has extended any form of erotic attention: she remains "on the most distant terms" with Adèle of whom she would have "preferred to know nothing"; she deems Robert "a man of ordinary caliber," unworthy of Edna's devotion, and is prompted to ask her friend, "why do you love him when you ought not to?" $(73,102,103)$. Yet in her 
goading of her friend to be "the soul that dares and defies," and via the ill-informed declaration which resounds in Edna's memory throughout the narrative that Robert "loves you, poor fool" (79, 102), Mademoiselle Reisz clearly incites Edna to act on her sexual desires. Much like the "creeping" lady in black churning her rosary beads, pale and "jaded" (26) in her avid pursuit of the lovers, Mademoiselle Reisz appears to feed off Edna's sensuality, her "sin." Indeed, she is explicitly associated with the lady in black in her description as "creeping up behind Edna" (57, emphasis added) to inquire whether she misses Robert on account of his absence. Despite her attempt to heed the Dionysian call, Edna is eventually drained, feeling "that old ennui overtaking her; the hopelessness . . . which came upon her like an obsession" (114). As a Dionysian handmaiden, Edna ultimately disregards Mademoiselle Reisz's "hunger," refusing to nourish the dead with her orgiastically induced blood offerings. Edna is left wondering "how she could have listened to her venom so long" and instead seeks a wholeness beyond the disembodied forms of representation expressed in the "uncanny half-human beings" $(60,35)$ of the Dionysian dream. It is the eroticism of the maternal sea and of the Madonna/Medusa, Adèle, that Edna ultimately chooses, not the hollow animalism of the Dionysian frenzy, nor the paradoxically related lifeless "deformity" (79) of Mademoiselle Reisz, the detached artist, who would exploit the Dionysian disciple and cruelly feed off the enslavement of her muse.

The Dionysian myth's claim on human sexual desire is further undermined via the novel's suggestion that the theological equation of sex with the feminine and with sinfulness has contributed to the emasculation of men. Where Dionysus and his male retinue and derivatives (e.g., satyrs, centaurs, and Pan) were well known for their carnal appetites and sexual vigor, the men of The Awakening seem rather impotent by comparison. Indeed, the Creole husband of the novel is described as having a "gangrene passion ... which has become dwarfed by disuse" (16). Certainly, Leonce Pontellier is representative not of the Dionysian order but its antithesis, as he worships at the altar not of the natural world, but of "his household gods": "Mr. Pontellier was very fond of walking about his house examining its various appointments and details, to see that nothing was amiss. He greatly valued his possessions, chiefly because they were his, and derived genuine pleasure from contemplating a painting, a statuette, a rare lace curtain ..." (62). Under the Victorian script for motherhood, Edna too becomes one of Leonce's precious possessions; he "worshipped her," along with the "cut glass, the silver, [and] the heavy damask" $(22,62)$ he has acquired. Such objectification allows Edna to "take her place with a certain dignity in the world of reality" and also ensures "that no trace of passion or excessive and fictitious warmth colored her affection" (22).

Chopin appears to suggest that men suffer equally as a result of the impairment and distortion of women's sexual passions in relation to the cultural primacy of the Angel Mother. Leonce's response to his wife's evident lack of consideration where he is concerned (the fact that she "evinced so little interest in things which concerned him and valued so little his conversation") sees him falsely complain that their son is suffering a high fever and ponder in agitation what he perceives as Edna's "inattention, her habitual neglect of the children" (6). His failed attempt to 
lure Edna to bed in her aroused state after her evening with Robert sees him in a similarly passive aggressive state, unable to assert his desires: "He drew up the rocker, hoisted his slippered feet on the rail, and proceeded to smoke a cigar. He smoked two cigars; then he went inside and drank another glass of wine" (39). The rocker, the slippers, and the orally fixated behavior strike a most unappealing picture of masculine sexual frustration. It would seem that where Leonce's (and, indeed, all men's) sexual desires are concerned, the cult of the Angel Mother has rendered him a figure seemingly authoritative yet tragically infantilized, ruthlessly controlling, yet ultimately impotent.

Despite the alignment of some of the novel's other men with the Dionysian ideal, they too ultimately exhibit the same ineffectuality, bewilderment, and hostility in the face of Edna's sexuality. Robert's younger brother Victor is constructed in express association with Dionysus at Edna's sumptuous dinner party: He has "a white silken scarf" draped over him and a "garland of roses" placed on his "black curls" (an arguably more sexually suggestive option than the death-related ivy generally associated with Dionysus) that transforms him into "a vision of Oriental beauty" (114). His transformation bewitches the dinner guests; one is said to lose "herself in a rhapsodic dream as she looked at him" while another murmurs the first line of Swinburne's poem on the peculiarities and torments of human desire, pleasure, pain, satiety, and death: "There was a graven image of Desire Painted with red blood on a ground of gold" (115). This literary reference hints at the dark, menacing potential of Victor's form of sensuality. Indeed, the superficial, even cruel, nature of Victor's sensual life is confirmed via the detached lecherousness of his account of the "stunning" Vera Cruz girls (130), and more obviously in his alternately teasing and dismissive approach to the young, barefoot Spanish girl, Mariequita, with whom it is hinted he has shared past sexual indiscretions.

The callous indifference and sense of predation underpinning nineteenthcentury ideals of masculine virility are even more ominously expressed in the novel via the Colonel, whose advice to his son-in-law to take a more authoritative approach with his daughter is juxtaposed with the observation that he is "perhaps unaware that he had coerced his own wife into her grave" (90). The cold, oblivious puerility characteristic of Leonce's, Victor's, and the Colonel's performances of masculinity is also mirrored in the construction of Edna's seducer, Alcee, who, "not overburdened with depth of thought or feeling," can be found waxing lyrical over "what a wicked, ill-disciplined boy he had been" (96). Yet, much like the frank discussions regarding the sexually licentious novel doing the rounds of the pension, the ultimately hollow masculine performances of sensuality in the narrative are a paradoxical manifestation of the inability to move beyond those established conventions that would impede the coupling of sexual pleasure with intimacy. As Brown argues, Edna ultimately discovers that her fellow holidaymakers on Grand Isle "possess a license [not] to behave as they feel, but permission to behave as though they did," so that a "measure of pseudo-sexual freedom" is exchanged for "acquiescence on the larger scale" $(40,41)$. The tragedy of such a condition in regard to the chasm repeatedly asserted between nineteenth-century men and women is expressed in 
the novel via Edna's vision of the bird in flight (the novel's obvious symbolic representation of female entrapment) and the ethereal naked man on the rocks whose "attitude was one of hopeless resignation as he looked toward a distant bird winging its flight away from him" (31).

Robert's aforementioned association with this forlorn figure in the novel reinforces his failure to match his would-be lover's passion and sensuality (paradoxically, given its link with the figure of Dionysus). The form of sensuality attributed Robert further serves to associate the emasculation of the novel's men to their culture's mother complex, revealing the problem inherent in the socially imposed compulsion to both worship the Mother and dominate her. Robert's sexualized reverence for mother-women reduces him to an infantile state; Adèle admonishes him for being "under my feet, like a troublesome cat," while Edna accuses him of being a "foolish boy" in response to his indirect marriage proposal $(12,138)$. Robert initially appears just as determined as Edna to pursue great passion: he gladly confesses to "his one time hopeless passion for Madame Ratignolle," characterized by "sleepless nights ... [and] consuming flames till the very sea sizzled when he took his daily plunge" (13). Yet his sexual desire is frequently accompanied by the "embarrassed and uneasy" demeanor of an inexperienced youth: his laugh becomes "boyish," and he speaks in a "high voice" with "an excited and irritable tone" $(51,24,52)$. His final, erotically charged meeting with Edna finds "his sensitive face . . . all disfigured with excitement"; again, he is "surprised, ill at ease, almost embarrassed" (35).

Robert's impotence, his inability to express his desire for the women in his life beyond the realm of infantile infatuation, also inspires his exploitative sexual conduct elsewhere. The novel implicates Robert's sexual escapades in Mexico via his newly acquired tobacco pouch, "a fantastic embroidered silk affair, evidently the handiwork of a woman” (129). Edna's possessive line of questioning in relation to the provider of this gift exposes Robert's indifference toward those with whom he would engage in sexual intimacies: he alludes to the "generosity" of the Vera Cruz girls in general and claims that "there are some people who leave impressions not so lasting as the imprint of an oar upon the water" (130). The novel similarly suggests that like his brother Vincent, Robert has engaged in some form of sexually exploitative behavior with the Spanish girl, Mariequita. It is arguably Robert's subscription to a conventional mode of relating to women, paradoxically characterized by both veneration and exploitation, that explains his bewilderment in the face of what he perceives as Edna's final denial of him: "I give myself where I choose. If he [Mr. Pontellier] were to say, Here, Robert, take her and be happy; she is yours," I should laugh at you both"” (138). Robert's inability to comprehend and rise to the challenge of Edna's quest for a new consciousness guarantees the validation of his fear that his current object of desire will not take his (essentially irresolute and contrived) sexual advances seriously. He protests against Edna's perception of him as "a comedian, a clown, a jack-in-the-box," yet his failure to see beyond the limiting gender prescriptions of his time ensures that Edna must venture elsewhere for one who might "stir her pulses and warm her blood" $(24,72)$. The sense of bliss evoked by the hopeful eroticism and fecundity of "the hum of bees, and the musky odor 
of pinks" in the novel's final line ultimately eludes Robert; for him, the pursuit of erotic fulfillment, of human connection, must tragically remain an experience more akin to "defending himself against a swarm of stinging insects" $(148,52)$.

The Awakening provides a provocative and ultimately optimistic exposé of the ways in which mythology and theology have long served to inform neurotic expectations and performances where the realms of the maternal and the sexual are concerned. Chopin's call for a dramatic shift in consciousness proposes a move away from the various limiting narratives that have long fashioned maternity and female sexuality in a relationship of irreconcilability. In engaging a variety of mythic mothers, Chopin is able to explore both the tensions and intrinsic connections existing between the realms of the maternal and the sexual within a specifically Victorian context. Despite a declining faith in mothers' "instincts," the advent of the New Woman, and the increasing separation of reproduction from sexual expression at the fin de siècle, the novel's meditations on the relationship between maternity and sexuality would still be met with fervent protest upon its publication. The Times Democrat's claim in its June 18 edition in 1899 that Chopin "fails to perceive that the relation of a mother to her children is far more important than the gratification of a passion," was reflective of the theme and tone common to many of the novel's initial reviews. Such critical responses attested to the continuing authority of the cult of True Womanhood and its attendant moral assumptions regarding human sexuality, gender distinction, and maternal responsibility. The infusion of Edna's fall from grace (or fall into grace, as the case may be) with both maternal and erotic elements would feed in to what were clearly persistent fears over the potentially destructive influence of mothers' sexuality. In drawing alternately on the various guises of the Great Mother archetype, Chopin explores the nature and origin of her society's deep-rooted ambivalence toward the mother figure and highlights the ways in which the Mother's nature, frequently constructed in dualistic terms, is almost always conveyed via the functioning of her sexuality. In resurrecting the Terrible Mother, Chopin's novel provokes a reconsideration of those elements of our nature frequently sublimated and forbidden. The novel's expanded concept of gendered relations, of human sexuality, and of the maternal asserts an end to the repression of various human energies, so that Mother can be reunited with herself, humanized, made "real" again.

\section{Works Cited}

Batten, Wayne. "Illusion and Archetype: The Curious Story of Edna Pontellier." Southern Literary Journal 18.1 (1985): 73-88. Print.

Brown, Susan Margaret. Giving Up the Unessential: Maternity and Sexuality in Kate Chopin's The Awakening and Edith Wharton's The Mother's Recompense. MA Thesis. Dalhousie University, 1989. Print.

Campbell, Joseph. The Hero with a Thousand Faces. London: Fontana P, 1993. Print.

Carroll, John. The Western Dreaming. Sydney: Harper Collins, 2001. Print.

Chopin, Kate. The Awakening (1899). New York: United Holdings Group, 15 January 2011 Kindle file. 
Euripides. Euripides: Bacchae. New York: Classic Books America, 2009. Print.

Freud, Sigmund. Sexuality and the Psychology of Love. New York: Collier Books, 1963. Print.

Frye, Katie Berry. "Edna Pontellier, Adele Ratignolle, and the Unnamed Nurse: A Triptych of Maternity in The Awakening. " Southern Studies: An Interdisciplinary Journal of the South 13.3/4 (2006): 45-66. Print.

Gilbert, Sandra M. “The Second Coming of Aphrodite: Kate Chopin's Fantasy of Desire.” Kenyon Review 5.3 (1983): 42-66. Print.

Giorcelli, Cristina. "Edna's Wisdom: A Transitional and Numinous Merging." New Essays on The Awakening. Ed. Wendy Martin. New York: Cambridge UP, 1988. 109-148. Print.

Gonzalez, Matilde Martin. "Sexual Politics and Mother-Women in The Awakening: A Foucauldian Analysis." Polifonias Textuales: Ensayos in Honorem Maria Del Carmen Fernandez Leal. Eds. Manuel Brito Oliva and Juan Ignacio. La Laguna: Revista Canaria de Estudios, 2001. 272-80. Print.

Hailey-Gregory, Angela. "Into the Realms of the Semi-Celestials': From Mortal to Mythic in The Awakening." Mississippi Quarterley 59 (2005): 295-312. Print.

The Holy Bible, King James Version. Cambridge Edition: 1769; King James Bible Online, 2015. $<$ wwwkingjamesbibleonline.org >. Web. 20 Feb. 2015.

Jung, Carl G. The Archetypes and the Collective Unconscious. 2nd ed. Trans. R.F.C. Hull. London: Routledge \& Kegan Paul, 1959. Print.

- Symbols of Transformation. Trans. R.F.C. Hull. Ed. XX, Bolingen Series. Second ed. Princeton, NJ: Princeton UP, 1956. Print.

Kearns, Katherine. “The Nullification of Edna Pontellier.” American Literature 63.1 (1991): 62-88. Print.

Lant, Kathleen Margaret. "The Siren of Grand Isle: Adele's Role in The Awakening. " Southern Studies 23.2 (1984): 167-75. Print.

Lupton, Mary Jane. "Women Writers and Death by Drowning." Amid Visions and Revisions: Poetry and Criticism on Literature and the Arts. Ed. Burney J. Hollis. Baltimore, MD: Morgan State UP, 1985. 95-101. Print.

Patmore, Coventry. "The Angel in the House.” Victorianweb.org 1891. Web.

Perry, Walter Copland. "The Sirens in Ancient Literature and Art." Choice Literature: A Monthly Magazine 2. (Sept.-Dec. 1883): 163. Print.

Rev. of The Awakening, by Kate Chopin, New Orleans Times Democrat 18 June 1899: 14-15. Web. <http:// people.virginia.edu/ sfr/enam854/summer/awcritf.html>. 14 Nov. 2015.

Schweitzer, Ivy. "Maternal Discourse and the Romance of Self-Possession in Kate Chopin's The Awakening." Boundary II (1990): 158-86. Print.

Stevens, Anthony. Archetype Revisited: An Updated Natural History of the Self. London: Brunner-Routledge, 2002. Print.

Streater, Kathleen M. “Adele Ratignolle: Kate Chopin's Feminist at Home in The Awakening." Midwest Quarterly 48 (2007): 406-16. Print.

Thurer, Shari L. The Myths of Motherhood: How Culture Reinvents the Good Mother. Boston, MA: Houghton Mifflin Company, 1994. Print.

Woodman, Marion, and Elinor Dickson. Dancing in the Flames: The Dark Goddess in the Transformation of Consciousness. Boston: Shambhala Publications, 1996. Print. 